\title{
INTERNALISASI PENDIDIKAN KARAKTER DI SEKOLAH
}

\author{
Oleh: \\ Arfandi \& Munif Shaleh \\ Fakultas Tarbiyah IAI Ibrahimy Situbondo \\ Arfandi.1985@gmail.com dan munifshaleh75@gmail.com
}

\begin{abstract}
:
Integrating character education in learning involvesome points. As we know that recognition pointis the essence of education that is the recognition of the human dignity of every individual human being. Furtherconsciousness point is important that teacher to be a good educator who is loved by students, and then internalization point that intended to student's behavior by teaching everyday in the learning process at school, mainly by teaching directly in the class on all of subject lessons. It has been mandated by UU SISDIKNAS 2003 that education is not only toforming the intelligent ofpeoples in Indonesia, but also got thepersonality or character.Education that has a purpose to forming smartand strong character peoples has been in resolution by Martin Luther King,"intelligence plus character, that is goal of true education".
\end{abstract}

Keywords: Internalisasi, Pendidikan Karakter, dan Character Building

\section{A. Pendahuluan}

Pada dasarnya pendidikan merupakan suatu usaha untuk membudayakan manusia atau memanusiakan manusia. Pendidikan merupakan unsur terpenting dalam aspek kehidupan, baik kehidupan dalam keluarga, masyarakat, maupun kehidupan bangsa dan Negara. Pendidikan pada umumnya dan pendidikan karakter (moral) pada khususnya merupakan sarana untuk mengadakan perubahan secara mendasar, karena membawa perubahan individu sampai ke akar-akarnya.

Pendidikan sebagai alat terpenting untuk menjaga diri dan memelihara nilai-nilai positif. Sebagaimana disebutkan dalam UndangUndang Dasar Negara Republik Indonesia Tahun 1945 Pasal 31 ayat (1) menyebutkan bahwa setiap warga negara berhak mendapatkan pendidikan dan ayat (3) menegaskan bahwa pemerintah mengusahakan dan menyelenggarakan satu sistem pendidikan nasional yang meningkatkan keimanan dan ketakwaan serta akhlak mulia dalam rangka mencerdaskan kehidupan bangsa yang merupakan salah satu tujuan 
negara Indonesia. ${ }^{1}$

Faktor utama dalam pembentukan pribadi manusia adalah pendidikan. Pendidikan adalah proses pengubahan sikap dan tata seseorang atau kelompok orang dalam usaha mendewasakan manusia melalui upaya pengajaran dan latihan. Pendidikan bertujuan membentuk orang agar mampu berfikir secara sistematis, bermoral benar, serta mampu menempatkan sisi baik dan buruknya kehidupan. ${ }^{2}$

Dalam kajian kebudayaan, nilai merupakan inti dari setiap kebudayaan. Dalam konstek ini, khususnya nilai-nilai moral yang merupakan sarana pengatur dari kehidupan bersama, sangat menentukan di dalam setiap kebudayaan. Lebih-lebih di era globalisasi yang berada dalam dunia yang terbuka, ikatan nila-nilai moral mulai melemah. Karakter anak bangsa berubah menjadi rapuh, mudah diterjang ombak, terjerumus dalam tren budaya yang melenakan, dan tidak memikirkan akibat yang ditimbulkan. Prinsip-prinsip moral, budaya bangsa, dan perjuangan hilang dari karakteristik mereka. ${ }^{3}$

Dengan sistem pendidikan yang baik, diharapkan muncul generasi penerus bangsa yang berkualitas dan mampu menyesuaikan diri untuk hidup bersama masyarakat, berbangsa dan bernegara. Hal ini menjadi respons terhadap perkembangan tuntutan global sebagai suatu upaya untuk mengadaptasikan sistem pendidikan yang mampu mengembangkan sumber daya manusia guna memenuhi tuntutan zaman yang sedang berkembang. Sehingga dengan adanya reformasi pendidikan, diharapkan pendidikan kita saat ini dapat berwawasan masa depan yang memberikan jaminan bagi pembentukan karakter manusia dan juga jaminan bagi perwujudan hak-hak asasi manusia dan prestasinya secara optimal guna kesejahteraan hidup di masa depan.

Jika kita menilik dunia pendidikan kita yang ada saat ini, dapat kita lihat bahwa pendidikan kita telah dijauhkan dari problematika yang ada dalam kehidupan nyata. Peserta didik (siswa) lebih dikenalkan pada penghafal teoritis, bukan diajarkan bagaimana cara mempraktikkan pemecahan suatu masalah (problem solving). Kita juga tidak bisa menampik fakta bahwa pendidikan menjadi sebuah entitas yang sangat menentukan nasib bangsa, manusia, serta masa depan kehidupan.

\footnotetext{
${ }^{1}$ Nurul Zuriah, 2011, Pendidikan Moral \& Budi Pekerti dalam Perspektif Perubahan, (Jakarta : PT. Bumi Aksara), Cet. Ke. 3, hlm. 7

2 Fathul Mujib, Super Power In Educating, (Jogjakarta : DIVA Press, 2012), Cet. Ke 1, hlm. 29

3Jamal Ma'mur Asmani, 2011, Buku Panduan Internalisasi Pendidikan Karakter di Sekolah, Jogjakarta, Cet. Ke 1, hlm. 8.

266 JURNAL LISAN AL-HAL
} 
Pendidikan yang diberikan kepada anak didik hanyalah sebatas pendidikan otak (kognitif), sedangkan pendidikan mengajarkan jati diri sebagai anak didik dan manusia tidak diberikan (afektif). Anak didik tidak diberikan pemahaman tentang pendidikan karakter atau kepribadian. ${ }^{4}$ Padahal pendidikan yang baik adalah pendidikan yang dapat membawa anak lebih bisa mengenali jati dirinya sendiri dan berkarakter (akhlak). Tujuan pendidikan tidak lagi diarahkan pada pembentukan kepribadian mandiri yang mampu menata kehidupan serta penghidupan siswa dalam situasi dan kondisi hidup yang kongkret dan kontemporer. Sekolah merasa sudah puas jika sudah mampu meluluskan 100\% siswanya ketika ujian nasional. Sekolah mengklaim dirinya sukses jika tahun ke tahun peminatnya semakin banyak, jumlah siswanya bertambah, dan bangunan sekolahnya semakin mewah. Sekolah tidak pernah berfikir secara mendalam tentang apa dan mana yang harus diuatamakan, tanpa pengabaian-pengabaian hal prinsipil.

Lemahnya lulusan pendidikan kita ini bukan saja karena faktor kemalasan dari siswa itu sendiri, namun juga karena ketidakmampuan guru dalam mendidik, kurikulum yang berorientasi pada kemampuan kognitif, metode pembelajaran yang masih konvensional, suasana kelas yang tidak menggairahkan, dan keringnya penanaman nilai-nilai relegius seperti karakter (akhlak) dalam diri siswa. Sekolah juga tidak pernah mengajarkan "long term structure of life" (struktur jangka panjang kehidupan) kepada para siswanya tentang bagaimana seseorang akan hidup untuk terus-menerus melakukan pembentukan karakter, hidup dengan cara hidupnya masing-masing, serta melakukan pengaturan di dalam masyarakat, bahkan menemukan identitasnya sendiri.

Pendidikan karakter sudah tentu bukan hanya tanggung jawab sekolah. Akan tetapi pendidikan karakter juga menjadi tanggung jawab bersama dari setiap individu yang bersentuhan dengan nilai dan kehidupan anak muda, dan hal itu dimulai sejak keluarga dan berkembang ke masyarakat, organisasi pemuda, perusahaan, pemerintah, bahkan media. ${ }^{5}$

Pentingnya internalisasi pendidikan karakter di sekolah secara intensif dengan keteladanan, kearifan, dan kebersamaan, baik dalam program intra kurikuler maupun ekstra kurikuler, sebagai pondasi kokoh

${ }^{4}$ Fathul Mujib, Super Power In Educating, (Jogjakarta : DIVA Press, 2012), Cet. Ke 1, hlm. 34

${ }^{5}$ Abdul Latief, Melihat Tanpa Mata, (Semarang : CV Gong Media Cakrawala, 2010), hlm. 9.

\begin{tabular}{l|l} 
JURNAL LISAN AL-HAL & 267
\end{tabular} 
yang bermanfaat bagi masa depan anak didik. Pendidikan karakter digaungkan dengan dahsyat agar lahir kesadaran bersama untuk membangun karakter generasi muda bangsa yang kokoh. Sehingga, mereka tidak terombang-ambing oleh modernisasi yang menjanjikan kenikmatan sesaat serta mengorbankan kenikmatan masa depan yang panjang dan abadi.

\section{B. Pembahasan}

\section{Mengenal Pendidikan Karakter}

Menurut Nursalam Sirajuddin, istilah karakter baru dipakai secara khusus dalam konteks pendidikan pada akhir abad ke-18. Pencetusnya adalah FW. Foerster. Terminologi ini mengacu pada sebuah pendekatan idealis-spiritualis dalam pendidikan, yang juga dikenal dengan teori pendidikan normatif. ${ }^{6}$ Lahirnya pendidikan karakter merupakan sebuah usaha untuk menghidupkan kembali pedagogi ideal-spiritual yang sempat hilang diterjang gelombang positivisme yang dipelopori oleh filsuf Prancis, Auguste Comte.

Karakter merupakan titian ilmu pengetahuan dan keterampilan. Pengetahuan tanpa landasan keperibadian yang benar akan menyesatkan, dan keterampilan tanpa kesadran diri akan menghancurkan. Karakter itu akan membentuk motivasi, yang dibentuk dengan metode dan proses yang bermartabat. Karakter bukan hanya penampilan lahiriyah, melainkan mengungkapkan secara implisit hal- hal yang tersembunyi.

M. Furqon Hidayatullah mengutip pendapatnya Rutland yang mengemukakan bahwa karakter berasal dari akar kata bahasa latin yang berarti "dipahat". Secara harfiyah, karakter artinya adalah kualitas mental atau moral, kekuatan moral, nama, atau reputasinya. Dalam kamus psikologi, dinyatakan bahwa karakter adalah kepribadian ditinjau dari titik tolak etis atau moral, misalnya kejujuran seseorang; biasanya mempunyai kaitan dengan sifat-sifat yang relatif tetap (Dali Gulo, 1982: 29).

Menurut Doni Koesoema Albertus, karakter diasosiasikan dengan temperemen yang memberinya sebuah definisi yang menekankan unsur psikososial yang dikaitkan dengan pendidikan dan konteks lingkungan. Karakter juga dipahami dari sudut pandang behavioral yang menekankan unsur somatopsikis yang dimilki oleh individu sejak lahir. Di sini, karakter dianggap sama dengan kepribadian. Kepribadian dianggap sebagai ciri

6 Jamal Ma'mua Asmani, Buku Panduan Internalisasi Pendidikan Karakter di Sekolah, (Jogjakarta, 2011), Cet. Ke 1, hlm. 27

268 JURNAL LISAN AL-HAL 
atau karakteristik atau gaya atau sifat khas dari diri sesorang yang bersumber dari bentukan -bentukan yang diterima dari lingkungan, misalnya pengaruh keluarga pda masa kecil dan bawaan seseorang sejak lahir. ${ }^{7}$

Pembentukan karakter merupakan salah satu tujuan pendidikan nasional. Pasal 1 UU SISDIKNAS tahun 2003 menyatakan bahwa diantara tujuan pendidikan nasional adalah mengembangkan potensi peserta didik untuk memiliki kecerdasan, kepribadian, dan akhlak mulia.

Amanah UU SISDIKNAS tahun 2003 itu bermaksud agar pendidikan tidak hanya membentuk insan indonesia cerdas, namun juga berkepribadian atau berkarakter. Sehingga, lahir generasi bangsa yang tumbuh berkembang dengan karakter yang bernapas nila-nilai luhur bangsa serta agama. Pendidikan yang bertujauan melahirkan insan cerdas dan berkarakter kuat itu juga pernah ditegaskan oleh Martin luther King, "intelligence plus character, that is goal of true education" (Kecerdasan yang berkarakter adalah tujuan akhir pendidikan yang sebenarnya). ${ }^{8}$ Karakter berupa kualitas kepribadian ini bukan barang jadi, tapi melalui proses pendidikan yang diajarkan secara serius, sungguh-sungguh, konsisten, dan kreatif yang dimulai dari unit terkecil dalam keluarga, kemudian masyarakat, dan lembaga pendidikan secara umum.

Menurut D. Yahya Khan, pendidikan karakter mengajarkan kebiasaan cara berfikir dan prilaku yang membantu individu untuk hidup dan bekerja sama sebagai keluarga, masyarakat, dan bangsa. Serta, membantu orang lain untuk membuat keputusan yang dapat dipertanggungjawabkan. Dengan kata lain, pendidikan karakter mengajarkan anak didik berfikir cerdas, mengaktivasi otak tengah secara alami. ${ }^{9}$

Berdasarkan grand design yang dikembangkan Kemendiknas (2010), secara psikologis dan sosial kultural, pembentukan karakter dalam diri individu meliputi fungsi dari seluruh potensi individu manusia (kognitif, afektif, konatif, dan psikotorik) dalam konteks intraksi sosial kultural (dalam keluarga, sekolah, dan masyarakat) dan berlangsung sepanjang hayat. Konfigurasi karakter dalam konteks totalitas proses

\footnotetext{
7 Doni Koesoema A. Pendidikan Karakter, Strategi Mendidik Anak di Zaman Global (Jakarta: Grasindo, 2010), hlm. 79-80. Sjarkawi, Pembentukan Kepribadian Anak; Intelektual, Emosional, dan Sosial sebagai wujud Integritas Membangun jati diri (Jakarta: Bumi Aksara, 2006), hlm. 11.

${ }^{8}$ Diknas. Kemdiknas. Go.id, yang diakses pada 11 Januari 2016

${ }^{9}$ D. Yahya Khan, Pendidikan Karakter Berbasis Potensi Diri; Mendongkrak Kualitas Pendidikan (Yogyakarta: Pelangi publishing, 2010), hlm. 1-2
} 
psikologis dan sosial-kultural tersebut dapat dikelompkkan menjadi olah hati (spritual and emotional development), olah fikir (intellectual development), olah raga dan kinestetik (phisical and kinesthetic development), serta olah rasa dan karsa (affective and creativity development).

Umumnya, para pakar pendidikan sependapat pentingnya upaya peningkatan pendidikan karakter pada jalur pendidikan formal. Meskipun demikian, ada perbedaan-perbedaan pendapat di antara mereka tentang pendekatan dan modus pendidikannya. Sebagian pakar menyarankan penggunaan pendekatan pendidikan moral yang dikembangkan di negaranegara barat, seperti pendekatan perkembangan moral kognitif, pendekatan analisis nilai, dan pendekatan klarifikasi nilai. Sebagian yang lain menyarankan penggunaan pendekatan tradisional, yakni melalui penanaman nilai-nilai sosial tertentu dalam diri peserta didik. ${ }^{10}$

Dalam pendidikan karakter di sekolah, semua komponen harus dilibatkan. Komponen tersebut meliputi isi kurikulum, proses pembelajaran dan penilaian, penanganan atau pengelolaan mata pelajaran, pengelolaan sekolah, pelaksanaan aktivitas atau kegiatan kokurikuler, pemberdayaan sarana prasarana, pembiayaan, dan etos kerja seluruh warga sekolah atau lingkungan.

Berdasarkan pembahasan tersebut dapat ditegaskan bahwa pendidikan karakter merupakan upaya-upaya yang dirancang dan dilaksanakan secara sistematis untuk membantu peserta didik memahami nila-nilai perilaku manusia yang berhubungan dengan Tuhaan Yang Maha Esa, diri sendiri, sesama manusia, lingkungan, dan kebangsaan. Kemudian, nilai-nilai tersebut dapat terwujud dalam pikiran, sikap, perasaan, perkataan, dan perbuatan berdasarkan norma-norma agama, hukum, tata krama, budaya, dan adat istiadat. ${ }^{11}$ Pendapat para pakar tersebut menegaskan tentang urgensi dan signifikansi pendidikan karakter dalam membangun moralitas, mentalitas, dan jiwa bangsa Indonesia yang sedang kehilangan jati diri dan kepribadian mereka.

\section{Ruang Lingkup Pendidikan Karakter}

Ruang lingkup pendidikan karakter (budi pekerti, moral dan akhlak) secara garis besar dapat dikelompokkan dalam tiga hal nilai akhlak yaitu sebagai berikut :

10 Kemendiknas, Pembinaan Pendidikan Karakter di Sekolah Menengah Pertama (Jakarta: 2010).

${ }^{11}$ Akhmadsudrajat.wordpress.com, yang diakses pada 5 juni 2011.

$270 \mid$ JURNAL LISAN AL-HAL 


\section{a. Akhlak terhadap Tuhan Yang Maha Esa}

Pertama, mengenal Tuhan sebagai pencipta. Manusia, hewan, tumbuh-tumbuhan, dan semua benda yang ada di sekeliling kita adalah makhluk ciptaan Tuhan Yang Maha Esa. Kita harus percaya kepada Tuhan yang menciptakan alam semesta ini, artinya kita wajib mengakui dan meyakini bahwa Tuhan yang maha esa itu memang ada. Kita harus beriman dan bertakwa padanya dengan yakin dan patuh serta taat dalam menjalankan segala perintah-Nya dan menjahui segala larangan-Nya.

Kedua, Tuhan sebagai pemberi (Pengasih, Penyayang). Tuhan Yang Maha Esa adalah Maha Pemberi, Pengasih, dan Penyayang. Asalkan kita meyakini akan keberadaannya dan akan kekuasaan dan kebesarannya maka Tuhan akan memberikan apapun yang kita minta. Dalam ajaran agama disebutkan " Mintalah kepada-Ku, niscaya aku akan memberinya". Oleh karena itu, janganlah kita merasa bosan untuk berdoa dan memohon, jangan pula cepat menyerah, tetapi harus tetap berusaha dengan sekuat tenaga.

Ketiga, Tuhan sebagai pemberi balasan (Baik dan Buruk). Selain Tuhan Maha Pemberi, juga akan selalu memberi balasan terhadap apa yang kita kerjakan dimanapun dan kapanpun. Oleh karena itu marilah kita berbuat baik dan beribadah sesuai dengan ajaran agama kita masingmasing. Keadaan kehidupan bermasyarakat akan lebih baik apabila semua umat beragama melaksanakan ajaran agamanya dengan penuh kesadaran, ketakwaan dan keikhlasan.

b. Akhlak terhadap sesama manusia

Pertama, terhadap diri sendiri. Setiap manusia harus mempunyai jati diri. dengan jati diri, seseorang mampu menghargai dirinya sendiri, mengetahui kemampuannya kelebihan dan kekurangannya. Kita harus berkelakuan dan berbuat baik setiap hari di mana saja. Kita pun harus berkarya demi kegunaan kita sendiri, keluarga, dan masyarakat bahkan bangsa dan negara.

Kedua, terhadap orang tua. Orang tua adalah pribadi yang ditugasi Tuhan untuk melahirkan, membesarkan, memelihara, dan mendidik kita. Maka sepatutnya seorang anak menghormati dan mencintai orang tua serta taat dan patuh kepadanya.

Ketiga, terhadap orang yang lebih tua. Bersikaplah hormat, menghargai dan mintalah saran, pendapat, petunjuk dan bimbingannya. Karena orang yang lebih tua dari kita pengetahuannya, pengalamannya, dan kemampuannya lebih dari kita. Keempat, terhadap sesama. Kita harus bergaul dengan semua teman tanpa memandang asal usul keturunan, suku bangsa, agama, maupun status sosial. 
Kelima, terhadap orang yang lebih mudah. Sebagai yang lebih tua jangan seenaknya saja memperlakukan teman kita yang lebih mudah, seharusnya yang lebih tua melindungi, menjaga, dan membimbing serta memberikan petunjuk, nasihat atau pendapat yang baik sehingga akan berguna bagi kehidupannya yang akan datang.

c. Akhlak terhadap lingkungan

Akhlak terhadap lingkungan meliputi akhlak terhadap flora dan fauna. Manusia tidak mungkin bertahan hidup tanpa adanya dukungan lingkungan alam yang sesuai, serasi seperti yang dibutuhkan. Untuk itulah kita harus mematuhi aturan dan norma demi menjaga kelastarian dan keserasian hubungan antara manusia dangan alam sekitarnya. Bumi Indonesia dikaruniai Tuhan berbagai fauna yang sangat banyak manfaatnya. Oleh karena itu wajib kita lestarikan, sehingga dapat memakmurkan rakyat.

\section{Prinsip-Prinsip Pendidikan Karakter}

Pendidikan karakter harus didasarkan pada prinsip-prinsip sebagai berikut: a). Mempromosikan nilai-nilai dasar etika sebagai basis karakter; b). Mengedentifikasi karakter secara komprehensif supaya mencakup pemikiran, perasaan, dan perilaku; c). Menggunakan pendekatan yang tajam, proaktif dan efektif untuk membangun karakter; d). Menciptakan komunitas sekolah yang memilki kepedulian; e). Memberi kesempatan kepada peserta didik untuk menunjukkan perilaku yang baik; f). Memiliki cakupan terhadap kurikulum yang bermakna dan menantang yang menghargai semua peserta didik, membangun karakter mereka, dan membantu mereka untuk sukses; g). Mengusahakan tumbuhnya motivasi diri pada para peserta didik; h). Memfungsikan seluruh staf sekolah sebagai komunitas moral yang berbagi tanggung jawab untuk pendidikan karakter dan setia pada nilai dasar yang sama; i). Adanya pembagian kepemimpinan moral dan dukungan luas dalam membangun inisiatif pendidikan karakter; j). Memfungsikan keluarga dan anggota masyarakat sebagai mitra dalam usaha membangun karakter; dan k). Mengevaluasi karakter sekolah, fungsi staf sekolah sebagai guru-guru karakter, dan manifestasi karakter positif dalam kehidupan peserta didik. Prinsip ini menjadi pegangan kepala sekolah dalam mlakukan monitoring kinerja staf-stafnya, perkembangan, dan dinamikanya. Sehingga, setiap problem bisa cepat dideteksi dan dicarikan solusinya secara praktis.

\footnotetext{
272 JURNAL LISAN AL-HAL
} 


\section{Peran Guru dalam Pendidikan Karakter}

Guru atau pendidik adalah orang yang memberikan ilmu pemgetahuan kepada peserta didik, untuk membentuk sumber daya manusia yang potensial dibidang pengembangan. Dalam hal ini pendidik memiliki tanggung jawab untuk membawa pada siswanya pada suatu kedewasaan atau tarap kematangan tertentu.

Guru tidak hanya semata-mata sebagai "Pengantar" yang Transfer Of Knowlege tetapi juga sebagai "Pendidik" yang Transfer Of Valuen dan sekaligus sebagai pembimbing yang memberikan pengarahan dan menuntut siswa dalam belajar. Sedangkan Adam dan Decey mengemukakan dalam basic principles of student teaching antara lain: guru sebagai pengajar, pemimpin kelas, pembimbing, pengatur lingkungan, partisipan, ekspeditor, perencana, motivator dan konselor". ${ }^{12}$

Guru merupakan sosok yang menjadi idola bagi anak didik. Keberadaannya sebagai jantung pendidikan tidak bisa dipungkiri. Baik atau buruknya pendidikan sangat tergantung pada sosok yang satu ini. Segala upaya sudah harus dilaksanakan untuk membekali guru dalam menjalankan fungsinya sebagai actor penggerak sejarah peradaban manusia dengan melahirkan kader-kader masa depan bangsa yang berkualitas paripurna, baik sisi akademik, afektif, dan psikomotorik. Menurut E. Mulyasa, fungsi guru itu bersifat multifungsi. Ia tidak hanya sebagai pendidik, tapi juga sebagai pengajar, pembimbing, pelatih, penasihat, pemburu, model dan teladan, pribadi, peneliti, pendorong kreativitas, pembangkit pandangan, pekerja rutin, pemindah kema, pembawa cerita, actor, emancipator, evaluator, pengawet, dan kulminator. ${ }^{13}$

Dalam konteks pendidikan karakter, peran guru sangat vital sebagai sosok yang diidolakan, serta menjadi sumber inspirasi dan motivasi murid-muridnya. Sikap dan perilaku seorang guru sangat membekas dalam diri seorang murid, sehingga ucapan, karakter, dan kepribadian guru menjadi cermin murid.

Menurut Sri Endang Susetiawati, dalam konteks system pendidikan di sekolah, sekurang-kurangnya pendidikan karakter harus memperhatikan beberapa hal sebagai berikut: hlm. 9

${ }^{12}$ Moh. Uzer Usman, Menjadi Guru Profesional, (Bandung : PT. Remaja Rosdakarya),

${ }^{13}$ E. Mulyasa, Menjadi Guru Profesional; Menciptakan Pembelajaran Kreatif dan Menyenangkan (Bandung: Roda, 2005), hlm. 37-64.

\begin{tabular}{l|l} 
JURNAL LISAN AL-HAL & 273
\end{tabular} 
a. Pendidikan karakter harus menempatkan kembali peran guru sebagai factor yang sangat penting dalam mengembangkan kepribadian peserta didik. Guru harus dikembalikan pada hakikatnya sebagai pendidik, bukan sebagai pengajar semata yang hanya mentransfer pengetahuan di ruang kelas. Sebagai pendidik, guru harus lebih berperan dalam mendidik dan mengembangkan kepribadian siswa melaui interaksi yang intensif, baik selama di ruang kelas maupun di luar kelas.

b. Pengembalian peran guru sebagai pendidik perlu diikuti oleh sebuah system pembelajaran yang sungguh-sungguh menempatkan sosok guru sebagai orang yang paling tahu tentang kondisi dan perkembangan anak didiknya, khususnya yang berkaitan dengan masalah kepribadian atau karakter siswa tersebut. Hal ini berarti masyarakat salah satu aspek penting dalam proses pembelajaran, yaitu system penilaian (evaluasi) perlu dikembalikan sebagai hak mutlak guru yang menentukan.

c. Sebagai bagian dari system pendidikan karakter, perlu digalakkan kembali sebuah system evaluasi yang lebih menitik beratkan pada penilaian aspek afektif, yang di sana karakter tersebut berada.

Menurut Nur Arifah D., guru atau pendidik memiliki tanggung jawab besar dalam menghasilkan generasi yang berkarakter, berbudaya, dan bermoral. Guru merupakan teladan bagi siswa dan memiliki peran yang sangat besar dalam pembentukan karakter siswa. Tugas-tugas manusiawi itu merupakan transformasi, identifikasi, dan pengertian tentang diri sendiri. Ketiga tugas guru itu harus dilaksanakan secara bersama-sama dalam kesatuan yang organis, harmonis, dan dinamis.

\section{Integrasi Pendidikan Karakter melalui Pembelajaran di Sekolah}

Dalam proses pembelajaran, unsur proses belajar memegang peranan yang sangat vital. "belajar adalah modifikasi atau memperteguh kelakuan melalui pengalaman". ${ }^{14}$ Dalam pembelajaran dikenal dengan tiga istilah, yaitu pendekatan, metode, dan teknik pembelajaran. Pendekatan pembelajaran bersifat lebih umum, dan berkaitan dengan seperangkat asumsi berkenaan dengan hakikat pembelajaran. Metode pembelajaran merupakan rencana menyeluruh tentang penyajian materi ajar secara sistematis dan berdasarkan pendekatan yang ditentukan.

\section{hlm. 27}

14 Oeamar Hamalik, Proses Belajar Mengajar, (Jakarta : PT Bumi Aksara, 2008.),

274 JURNAL LISAN AL-HAL 
Teknik pembelajaran adalah kegiatan sefesifik yang diimplementasikan dalam kelas atau laboratorium sesuai dengan pendekatan dan metode yang dipilih. Dengan demikian, dapat ditegaskan bahwa pendekatan lebih bersifat aksiomatis, metode bersifat prosedural, dan teknik bersifat operasional (Abdul Majid, 2005). Meskipun demikian, beberapa ahli dan praktisi sering kali tidak membedakan ketiga istilah tersebut secara tegas. Sering kali, mereka menggunakan ketiga istilah tersebut dengan pengertian yang sama.

Pendidikan karakter yang terpadu dalam pembelajaran merupakan pengenalan nilai-nilai, diperolehnya kesadaran akan pentingnya nilai-nilai, dan internalisasi nilai-nilai ke dalam tingkah laku peserta didik sehari-hari melaui proses pembelajaran, baik yang berlangsung di dalam maupun luar kelas pada semua mata pelajaran.

Kegiatan pembelajaran bertujuan menjadikan peserta didik menguasai kompetensi (materi) yang ditargetkan. Serta, dirancang untuk menjadikan peserta didik mengenal, menyadari atau peduli, dan menginternalisasi nilai-nilai dalam bentuk perilaku.

Dalam struktur kurikulum SMP, pada dasarnya setiap mata pelajaran memuat materi-materi yang berkaitan dengan karakter. Secara subtansif, setidaknya terdapat dua mata pelajaran yang terkait langsung dengan pengembangan budi pekerti dan akhlak mulia, yaitu pendidikan agama dan pendidikan kewarganegaraan. Kedua mata pelajaran tersebut secara langsung mengenalkan nilai-nilai, dan sampai taraf tertentu menjadikan peserta didik peduli dan menginternalisasi nilai-nilai. Integrasi pendidikan karakter pada mata pelajaran mengarah pada internalisasi dalam tingkah laku sehari-hari proses pembelajaran dari tahapan perencanaan, pelaksanaan, dan penilaian. Untuk madrasah dengan muatan lokal yang diajarkan secara maksimal, pendidikan karakter mempunyai medan teramat luas. Sehingga, karakter anak didik di madrasah seharusnya lebih dinamis, kreatif, dan inovatif.

\section{Metodologi Internalisasi Pendidkan Karakter di Sekolah}

Pada era 1990-an, para reformer pendidikan berusaha mencari jawaban bagi dua pertanyaan fundamental : (1) seberapa baikkah para pelajar itu belajar di kelas? Dan, (2) seberapa efektifkah para guru itu mengajar di kelas? Penilaian kelas merespons secara langsung terhadap hal-hal mengenai pembelajaran yang lebih baik dan pengajaran yang lebih efektif. 15

15 Moh. Sholeh Hamid, Standart Mutu Penilaian dalam Kelas, (Jogjakarta : DIVA 
Di era global ini setiap sekolah hendaknya selalu melakukan berbagai inovasi pembelajaran untuk mendasari dan mencetak sumber daya manusia yang berkualitas. Pembelajaran yang dilakukan guru hendaknya dapat memberikan situasi di mana siswa dapat secara optimal mengembangkan kompetensi dirinya sesuai perkembangan umur dan intelektual masing-masing siswa. Situasi ini dapat terwujud jika guru diberikan keleluasaan mengelola kelas sesuai karakteristik mata pelajaran masing-masing, karakteristik siswa, dan keleluasaan melakukan penilaian sesuai perkembangan masing-masing siswa. Di dalam kelas guru harus melakukan berbagai inovasi dan strategi pembelajaran, mengelola kelas, menata ruang, menata alat peraga, menata tempat duduk sesuai karakteristik mata pelajaran masing-masing dan sebagainya

Strategi Pembelajaran adalah "Cara-cara yang akan digunakan oleh pengajar untuk memilih kegiatan belajar yang akan digunakan selama proses pembelajaran". 16 Strategi pembelajaran merupakan keputusan instruktur dalam menetapkan berbagai kegiatan yang akan dilaksanakan, sarana prasarana yang digunakan, termasuk jenis media yang digunakan, materi yang diberikan dan metodologi yang digunakan dalam pelaksanaan kegiatan belajar mengajar.

Pendidikan karakter jelas membutuhkan metodologi yang efektif, aplikatif, dan produktif agar tujuan bisa tercapai dengan baik. Menurut Doni Koesoema A., metodologi pendidikan karakter adalah sebagai berikut.

a. Pengajaran, mengajarkan pendidikan karakter dalam rangka memperkenalkan pengetahuan teoretis tentang konsep-konsep nilai. Pemahaman konsep ini mesti menjadi bagian dari pemahaman dan pengertian tentang nilai-nilai yang dipahami oleh para guru dan pendidik dalam setiap perjumpaan mereka.

b. Keteladanan, keteladanan menjadi salah satu hal klasik bagi berhasilnya sebuah tujuan pendidikan karakter. Tumpuan pendidikan karakter ada pada pundak guru. Konsistensi dalam mengajarkan pendidikan karakter tidak sekadar melalui sesuatu yang dikatakan melalui pembelajaran di kelas, melainkan nilai itu juga tampil dalam diri sang guru, dalam kehidupannya yang nyata di luar kelas. Karakter guru (meskipun tidak selalu) menentukan warna kepribadian anak didik.

Pres, 2011), hlm.55

${ }_{16}$ Hamzah B. Uno, Model pembelajaran , (Jakarta : PT Bumi Aksara, 2009), hlm. 3

$$
276 \text { JURNAL LISAN AL-HAL }
$$


c. Menentukan Prioritas, lembaga pendidikan memiliki prioritas dan tuntutan dasar atas karakter yang ingin diterapkan di lingkungan mereka. Pendidikan karakter menghimpun banyak kumpulan nilai yang dianggap penting bagi pelaksanaan dan realisasi atas visi lembaga pendidikan. Oleh karena itu, lembaga pendidikan mesti menentukan tuntutan standar atas karakter yang akan ditawarkan kepada peserta didik sebagai bagian dari kinerja kelembagaan mereka.

d. Praksis Prioritas, unsur lain yang sangat penting bagi pendidikan karakter adalah bukti dilaksanakannya prioritas nilai yang menjadi visi kinerja pendidikannya, lembaga pendidikan msesti mampu membuat verifikasi sejauh mana visi sekolah telah dapat direalisasikan dalam lingkup pendidikan skolastik melalui berbagai macam unsur yang ada di dalam lembaga pendidikan itu sendiri.

e. Refleksi, Karakter yang ingin dibentuk oleh lembaga pendidkan melalui berbagai macam program dan kebijakan senantiasa perlu dievaluasi dan direfleksikan secara berkesinambungan dan kritis. Sebab, sebagaimana yang dikatakan Socrates, "Hidup yang tidak direfleksikan merupakan hidup yang tidak layak dihayati." Tanpa ada usaha untuk melihat kembali sejauh mana proses pendidikan karakter ini direfleksikan dan dievaluasi, tidak akan pernah terdapat kemajuan. Refleksi merupakan kemampuan sadar ini, manusia mampu mengatasi diri dan meningkatkan kualitas hidupnya dengan lebih baik. Jadi, setelah tindakan dan praksis pendidikan karakter itu terjadi, perlulah diadakan semacam pendalaman dan refleksi untuk melihat sejauh mana lembaga pendidikan telah berhasil atau gagal dalam melaksanakan pendidikan karakter. ${ }^{17}$

\section{Simpulan}

Dari penjelasan di atas, maka dapat ditarik pemahaman, bahwa faktor utama dalam pembentukan pribadi manusia (karakter) adalah pendidikan. Pendidikan adalah proses pengubahan sikap dan tata seseorang atau kelompok orang dalam usaha mendewasakan manusia melalui upaya pembelajaran dan latihan. Pendidikan karakter yang terpadu dalam pembelajaran merupakan pengenalan nilai-nilai, diperolehnya kesadaran akan pentingnya nilai-nilai, dan internalisasi nilai-nilai ke dalam tingkah laku peserta didik sehari-hari melaui proses

17 Doni Koesoema A. Pendidikan Karakter, Strategi Mendidik Anak di Zaman Global (Jakarta: Grasindo, 2010), hlm. 212-217. 
pembelajaran di sekolah, baik yang berlangsung di dalam maupun luar kelas pada semua mata pelajaran. Hal ini, sebagaimana yang telah diamanahkan oleh UU SISDIKNAS tahun 2003 bahwa pendidikan tidak hanya membentuk insan indonesia cerdas, namun juga berkepribadian atau berkarakter. Sehingga, lahir generasi bangsa yang tumbuh berkembang dengan karakter yang bernafas nila-nilai luhur bangsa serta agama. Pendidikan yang bertujuan melahirkan insan cerdas dan berkarakter kuat itu juga pernah ditegaskan oleh Martin luther King, "intelligence plus character, that is goal of true education" (Kecerdasan yang berkarakter adalah tujuan akhir pendidikan yang sebenarnya).

\section{DAFTAR PUSTAKA}

A., Doni Koesoema Pendidikan Karakter, Strategi Mendidik Anak di Zaman Global, Jakarta: Grasindo, 2010.

Ary Ginanjar Agustian. Rahasia Sukses Membangun Kecerdasan Emosi dan Spiritual, ESQ, Emotional Spiritual Quotient. Jakarta: Arga. 2008.

Asmani, Jamal Ma'mur, Buku Panduan Internalisasi Pendidikan Karakter di Sekolah, Jogjakarta, 2011.

B. Uno, Hamzah, Model pembelajaran , Jakarta : PT Bumi Aksara, 2009.

Hamalik, Oeamar, Proses Belajar Mengajar, Jakarta : PT Bumi Aksara, 2008.

Hamid, Moh. Sholeh, Standart Mutu Penilaian dalam Kelas, Jogjakarta : DIVA Pres, 2011.

Kemendiknas, Pembinaan Pendidikan Karakter di Sekolah Menengah Pertama Jakarta: 2010.

Khan, D. Yahya, Pendidikan Karakter Berbasis Potensi Diri; Mendongkrak Kualitas Pendidikan. Yogyakarta: Pelangi publishing, 2010.

Mujib, Fathul , Super Power In Educating, Jogjakarta : DIVA Press, 2012.

Mulyasa, E. Menjadi Guru Profesional; Menciptakan Pembelajaran Kreatif dan Menyenangkan. Bandung: Roda, 2005.

Mustakim, Bagus, Pendidikan Karakter, Membangun Delapan Karakter Emas Menuju Indonesia Bermartabat. Yogyakarta: Samudra Biru, 2011.

Nurul Zuriah, Pendidikan Moral \& Budi Pekerti dalam Perspektif Perubahan, Jakarta : PT. Bumi Aksara, 2011.

Raka, Gede at. All. Pendidikan Karakter di Sekolah; dari Gagasan ke Tindakan. Jakarta: Elex MediaKomputindo, 2002.

Sjarkawi, Pembentukan Kepribadian Anak; Intelektual, Emosional, dan

$278 \mid$ JURNAL LISAN AL-HAL 
"Volume 8, No. 2, Desember 2016"

Sosial Sebagai wujud Integritas Membangun jati diri. Jakarta: Bumi Aksara, 2006.

Uzer Usman, Moh. Menjadi Guru Profesional, Bandung: PT. Remaja Rosdakarya. 
"Internalisasi Pendidikan Karakter"

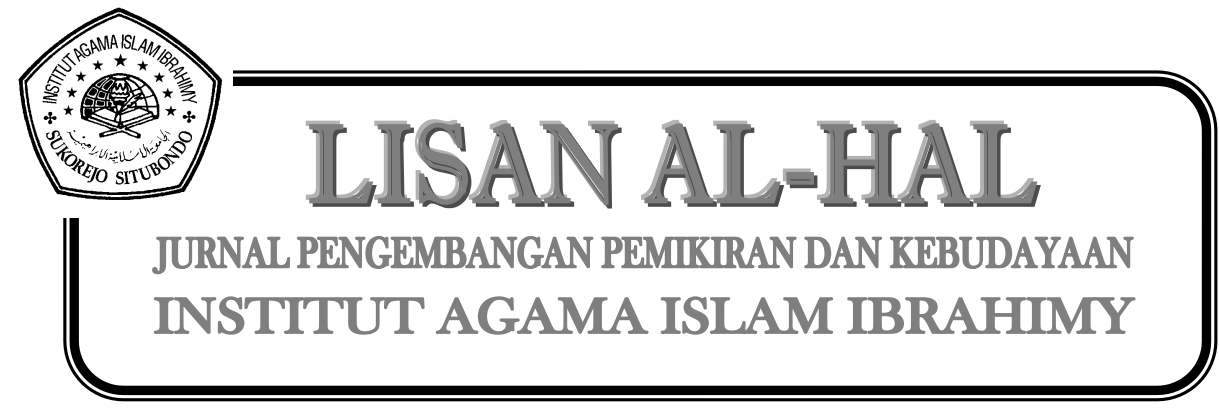

$280 \mid$ JURNAL LISAN AL-HAL 